\title{
Mapping of Biomass Production of Land Damage Assessment to Reduce Environmental Changes In East Java Probolinggo
}

\author{
Ali Mahrus ${ }^{1}$, Hariyadi Bambang Wicaksono ${ }^{2}$, Nurlina $^{3}$, Hasyim Cholil ${ }^{4}$, and Mudjanarko \\ Sri Wiwoho, \\ 1,2,3 Agriculture, Agrotechnology Department, Ketintang VII/2, Merdeka University, Indonesia,60232 \\ 4 Civil Engineering, Civil Department, Darul Ulum University, Gus Dur No.29A, Mojopahit, \\ Jombang 61419 Indonesia \\ 5 Civil Engineering, Civil Department, Narotama University,Arief Rachman Hakim No. 51, \\ Surabaya, 60117,Indonesia
}

\begin{abstract}
The increasing population in Probolinggo, East Java, Indonesia require residential land. Excessive use of housing land reduces agricultural lands will impact environmental changes surrounding area. Limitations of use of agricultural land due to the construction of housing in need of good quality soil in increasing food production. This study aims to determine the value of the damage of Land For Biomass Production to reduce the environmental changes surrounding area. The method used in the form of land damage mapping biomass production. Variable ground damage assessment status of each parameter is done by weighting and scoring methods. The results showed that the status of land degradation in the District Paiton is the status of damaged land with an area of 3922.74 hectares of land and/or land for biomass production with an area of $147,234.60$ hectares, or approximately $2.66 \%$ of the total area of the District Paiton. The area of a degraded land category is at the Village Bhinor, Jabung comb, middle Alas, Kalijajar wetan and Plampang.
\end{abstract}

\section{Introduction}

The total area of ProbolinggoSub districtis approximately $1696.16 \mathrm{~km}^{2}$ consisting $147,74 \mathrm{~km}^{2}$ of settlements, $373.13 \mathrm{~km}^{2}$ of Rice Field, $513.80 \mathrm{~km}^{2}$ of moor, $32,81 \mathrm{~km}^{2}$ of plantation, $426.46 \mathrm{~km}^{2}$ of forest, $13.99 \mathrm{~km}^{2}$ of pond/pool, and $188.23 \mathrm{~km}^{2}$ of other utilization [1]. Terrestrial environment is a stretch of the earth's surface which is the unity of space with energy, materials of various types of biomass and living creatures and man with all his behavior. Terrestrial environment with its high environmental or natural resources leads a lot of human activity. Some areas of land are used as residential, industry, mining, agriculture, livestock farming, aquaculture fresh water and other areas. Many areas of land

\footnotetext{
*Corresponding author: sri.wiwoho@narotama.ac.id
} 
have experienceddegradation; one of which is due to soil erosion as a result of high rainfall, low vegetation covered-land, conversion of land from forests to agricultural crops, steepland utilization and misused of land can cause erosion, sedimentation and siltation of river. As a result, river water flow decrease and cause flooding and degradation of soil fertility which in turn decrease agricultural production and eventually farmers' income. Control of terrestrial environment damage can be grouped with preventive and reactive approaches. Preventive approach is performed through consistent spatial planning and appropriate space management and the use of environmentally friendly technologies. Reactiveapproachincludes conducting outreach to the community in order to manage the land damaged by erosion and pollution as well as to avoid the occurrence of land conversion. Preserving environment is not merely the responsibility of government or heads of state, but every human being on earth. Everyone should make an effort to save the environment in accordance with the capacity of each;the involvement of individual beneficial for the realization of habitableearth for the next generation. Measurement procedure for the of standard criteria of damaged land for biomass production is structured to explain steps to be performed by the regent/mayor related to monitoring and surveillance.

\section{Research Methods}

The research was conducted at critical lands inside and outside forest areas in five villages in PaitonSub district, Probolinggo in 2014. Case study method, with land based on a survey by scale detail in the ratio of 1: 10,000 or 1: 25,000 was used as an object. Data was collected and then proceededto describeobjective conditions of critical land in Probolinggo as a basis for policy making ofdeveloping the damaged land into productive one. Soil sampling was carried out by using overlay or superimpose on some thematic maps to obtain an overview of the areas that can potentially damage the land/soil and from the result of coordination with relevant agencies.

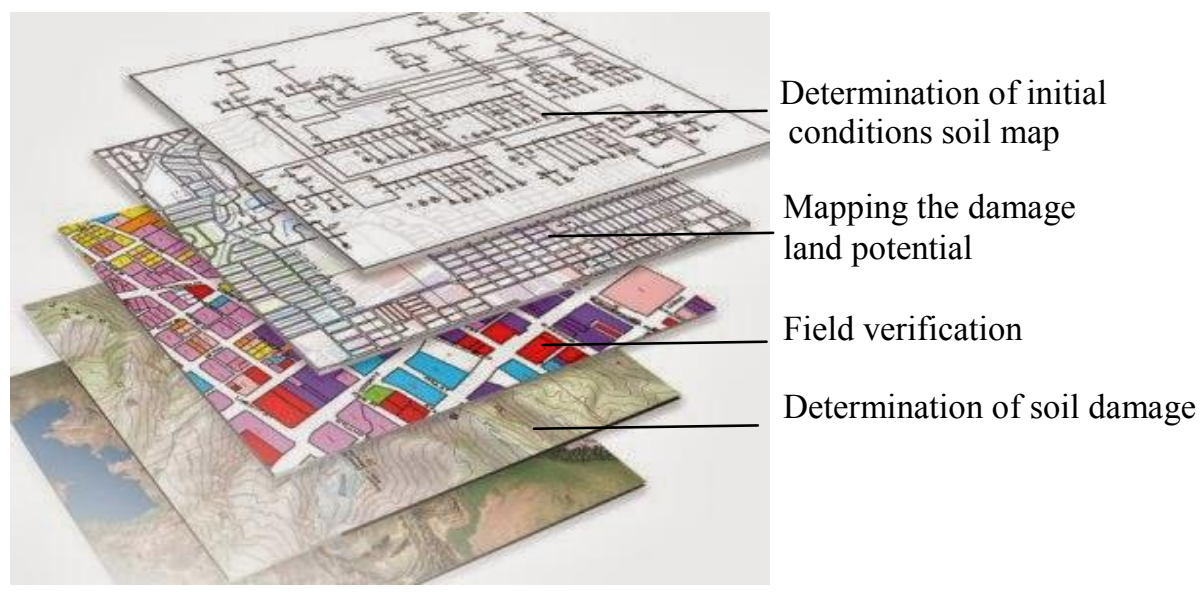

Fig. 1. Illustration of the superimpose / overlay thematic map for the determination of land analysis unit.

Source: Data Analysis Year 2014. [1] 


\section{Results And Discussion}

Based on the analysis of land use map overlay (for biomass production), slope maps, soil maps and rainfall maps in Probolinggo Sub district, 8 land units for four study location villages inPaiton Sub districts. Theresult of the observation and interpretation is explained as follow: [2-9]

\subsection{Paiton Subdistrict}

Paiton sub district includesBhinor, Jabung Sisir, Alas Tengah, Kalijajar Wetan dan Plampangvillages. The soil characteristics ineach village vary as follow:

\subsubsection{The Bhinor Village (Plantation)}

Table 1. Results of Analysis and Interpretation of Land Damage in Bhinor (P) Village, Paiton Sub district,Probolinggo.

\begin{tabular}{|c|c|c|c|c|}
\hline No. & Parameter & $\begin{array}{l}\text { Critical } \\
\text { threshold } \\
(\text { PP150 / 2000) }\end{array}$ & $\begin{array}{l}\text { Observations/ } \\
\text { Analysis }\end{array}$ & $\begin{array}{l}\text { Exceeding/Not } \\
\text { exceeding }\end{array}$ \\
\hline 1. & Solum thickness & $<20 \mathrm{~cm}$ & $>90 \mathrm{~cm}$ & not Critical \\
\hline 2. & Surface rocks & $40 \%$ & $<3 \%$ & not Critical \\
\hline 3. & fraction composition & \begin{tabular}{|lr}
$<18 \%$ colloidal \\
$80 \%$ & sand \\
kuarsitik & \\
\end{tabular} & $6.26 \%$ & not Critical \\
\hline 4. & weight content & $1.4 \mathrm{~g} / \mathrm{cm}^{3}$ & $1.18 \mathrm{~g} / \mathrm{cm}^{3}$ & not Critical \\
\hline 5. & porosity Total & $<30 \% ;>70 \%$ & $50.52 \%$ & not Critical \\
\hline 6. & $\begin{array}{l}\text { The degree of release } \\
\text { of water }\end{array}$ & $\begin{array}{l}<0.7 \mathrm{~cm} / \text { hour; } \\
8.0 \mathrm{~cm} / \text { hour }\end{array}$ & $1.16 \mathrm{~cm} /$ hour & not Critical \\
\hline 7. & $\mathrm{pH}\left(\mathrm{H}_{2} \mathrm{O}\right) 1: 2,5$ & $<4.5 ;>8.5$ & 6.6 & not Critical \\
\hline 8. & Electrical Conductivity & $4.0 \mathrm{mS} / \mathrm{cm}$ & $0.259 \mathrm{mS} / \mathrm{cm}$ & not Critical \\
\hline 9. & redox & $<200 \mathrm{mV}$ & $59.0 \mathrm{mV}$ & Critical \\
\hline 10. & number of Microbes & $\begin{array}{lll}<10 & & \\
\text { soil } & & \\
\end{array}$ & $\begin{array}{l}\text { Bacteria }>300 \times 10 \\
9 \\
\text { Mushrooms } 16 \quad x \\
10^{9}\end{array}$ & not Critical \\
\hline
\end{tabular}

Note: Exceeding $=$ Critical

No $=$ Not Critical

Based on the land conditionobtained from field, the redox was low by $59.0 \mathrm{mV}$ less than $200 \mathrm{mV}$ indicating that the land was water saturated and low oxygen presented in the soil that fe and $\mathrm{mn}$ elements are conditioned in redox state, rooting faces obstacles in its development.

The solution to restore land is by manufacturing irrigation channels and drainage to enable oxygen penetrates into the soil pores, continuousorganic fertilizer givenin ech soil cultivation is preferable to increase the pore space of soil and organic matter availability. 


\subsubsection{Bhinor Village (Rain fed rice field)}

Table 2. Results of Analysis and Interpretation of BhinorVillageLand Damage (STH), Paiton Sub district,Probolinggo.

\begin{tabular}{|c|c|c|c|c|}
\hline No. & Parameter & $\begin{array}{l}\text { Critical } \\
\text { threshold } \\
(\text { PP150/2000) }\end{array}$ & $\begin{array}{l}\text { Observations } \\
\text { Analysis }\end{array}$ & $\begin{array}{l}\text { Exceeding / Not } \\
\text { exceeding }\end{array}$ \\
\hline 1. & Solum thickness & $<20 \mathrm{~cm}$ & $>90 \mathrm{~cm}$ & not Critical \\
\hline 2. & Surface rocks & $40 \%$ & $<3 \%$ & not Critical \\
\hline 3. & fraction composition & $\begin{array}{lr}<18 \% \text { colloidal } \\
80 \% & \text { sand } \\
\text { kuarsitik } & \\
\end{array}$ & $3.24 \%$ & not Critical \\
\hline 4. & weight content & $1.4 \mathrm{~g} / \mathrm{cm} 3$ & $1.26 \mathrm{~g} / \mathrm{cm}^{3}$ & not Critical \\
\hline 5. & porosity Total & $<30 \% ;>70 \%$ & $46.13 \%$ & not Critical \\
\hline 6. & $\begin{array}{l}\text { The degree of release } \\
\text { of water }\end{array}$ & $\begin{array}{l}<0.7 \mathrm{~cm} / \text { hour; } \\
8.0 \mathrm{~cm} / \text { hour }\end{array}$ & $1.51 \mathrm{~cm} /$ hour & not Critical \\
\hline 7. & $\mathrm{pH}\left(\mathrm{H}_{2} \mathrm{O}\right) 1: 2,5$ & $<4.5 ;>8.5$ & 6.6 & not Critical \\
\hline 8. & Electrical Conductivity & $4.0 \mathrm{mS} / \mathrm{cm}$ & $0.176 \mathrm{mS} / \mathrm{cm}$ & not Critical \\
\hline 9. & Redox & $<200 \mathrm{mV}$ & $55.2 \mathrm{mV}$ & Critical \\
\hline 10. & number of Microbes & $\begin{array}{llll}<10 & 2 \mathrm{cfu} & / \mathrm{g} \\
\text { soil } & & & \\
\end{array}$ & $\begin{array}{l}\text { Bacteria } 2 \times 10^{9} \\
\text { Mushrooms } 2 \times 10\end{array}$ & not Critical \\
\hline
\end{tabular}

Note: Exceeding $=$ Critical

No $=$ Not Critical

A constraint faced in Bhinor village is similartoBhinor village plantation with constraints on redox by $55.2 \mathrm{mv}$.Intensive processing and long period ofland inundationhampers oxygen fromentering soil. This causes toxic elements highlyinfluenced the development of plant roots.

The solution to be taken to overcome critical land is creating irrigation channels and drainage as well as giving organic fertilizer and manure or hay or remnants of harvests. The soil should be also processed as minimally toincrease pore space with minimum inundation.

\subsubsection{Bhinor Village (Production Forest)}

Table 3. Results of Analysis and Interpretation of the BhinorVillage Land Damage (HP), PaitonSub district, Probolinggo.

\begin{tabular}{|l|l|l|l|l|}
\hline No. & Parameter & $\begin{array}{l}\text { Critical } \\
\text { threshold } \\
(\mathrm{PP} 150 / 2000)\end{array}$ & $\begin{array}{l}\text { Observations } \\
\text { Analysis }\end{array}$ & $\begin{array}{l}\text { Exceeded / } \\
\text { Not }\end{array}$ \\
\hline 1. & Solumn thickness & $<20 \mathrm{~cm}$ & $>90 \mathrm{~cm}$ & not Critical \\
\hline 2. & Surface rocks & $40 \%$ & $<5 \%$ & not Critical \\
\hline 3. & fraction composition & $\begin{array}{l}<18 \% \text { colloidal } \\
80 \% \text { sand } \\
\text { kuarsitik }\end{array}$ & $3,07 \%$ & not Critical \\
\hline 4. & weight content & $1.4 \mathrm{~g} / \mathrm{cm}^{3}$ & $1.16 \mathrm{~g} / \mathrm{cm}^{3}$ & not Critical \\
\hline 5. & porosity Total & $<30 \% ;>70 \%$ & $51.48 \%$ & not Critical \\
\hline 6. & The degree of release of & $<0.7 \mathrm{~cm} /$ hour; & $1.32 \mathrm{~cm} /$ hour & not Critical \\
\hline
\end{tabular}




\begin{tabular}{|l|l|l|l|l|}
\hline & water & $8.0 \mathrm{~cm} /$ hour & & \\
\hline 7. & $\mathrm{pH}\left(\mathrm{H}_{2} \mathrm{O}\right) 1: 2,5$ & $<4.5 ;>8.5$ & 6.8 & not Critical \\
\hline 8. & Electrical Conductivity & $4.0 \mathrm{mS} / \mathrm{cm}$ & $0.090 \mathrm{mS} / \mathrm{cm}$ & not Critical \\
\hline 9. & redox & $<200 \mathrm{mV}$ & $42.9 \mathrm{mV}$ & Critical \\
\hline 10. & number of Microbes & $<10^{2} \mathrm{cfu} / \mathrm{g}$ soil & $\begin{array}{l}\text { bacteria }- \\
\text { mushrooms - }\end{array}$ & Critical \\
\hline
\end{tabular}

Note: Exceeding $=$ Critical

No $=$ Not Critical

Bhinor village land, Paiton subdistrict is categorizedas critical condition with problems in the redox and the number of microbes. However, there are many alternative solutions available. The characteristic of production forest is similar to other Bhinor land utilization. The difference is on production forest land withzero number of microbes. This could be caused by redox reactions and organicpesticide use that hampers bacteria growth microbial life in the soil.

Soil should not be cultivated intensivelyas the more intensive soil cultivation the higher the compaction and surface water frequently floods impermeable surfaceslayer. Critical threshold for BhinorVillage area is needs attentionto prevent it from happening again that soil physical and chemicalpropertiesdo not degrade the land quality. Land management should be maintained by creating irrigation channels and drainage as well as minimum tillage for annual or seasonal crops is adapted to the suitability of land.Organic pesticidesis better used for eradication of pests and diseases to avoid bacterial decomposers death due to poisoning elements of inorganic pesticides. Organic materials in addition to the manure and dry leaves are more advisable.

\subsubsection{Bhinor Village (Moor)}

Table 4. Results of Analysis and Interpretation of the BhinorVillage Land Damage (T), PaitonSub district, Probolinggo.

\begin{tabular}{|l|l|l|l|l|}
\hline No. & Parameter & $\begin{array}{l}\text { Critical threshold } \\
(\mathrm{PP} 150 / 2000)\end{array}$ & Observations/Analysis & $\begin{array}{l}\text { Exceeded } \\
\text { Not }\end{array}$ \\
\hline 1. & Solumn thickness & $<20 \mathrm{~cm}$ & $>90 \mathrm{~cm}$ & not Critical \\
\hline 2. & Surface rocks & $40 \%$ & $<5 \%$ & not Critical \\
\hline 3. & fraction composition & $\begin{array}{l}<18 \% \text { colloidal } \\
80 \% \text { sand kuarsitik }\end{array}$ & $14.80 \%$ & not Critical \\
\hline 4. & weight content & $1.4 \mathrm{~g} / \mathrm{cm}^{3}$ & $1.31 \mathrm{~g} / \mathrm{cm}^{3}$ & not Critical \\
\hline 5. & porosity Total & $<30 \% ;>70 \%$ & $43.89 \%$ & not Critical \\
\hline 6. & $\begin{array}{l}\text { The degree of release } \\
\text { of water }\end{array}$ & $\begin{array}{l}<0.7 \mathrm{~cm} / \text { hour; } \\
8.0 \mathrm{~cm} / \text { hour }\end{array}$ & $0.20 \mathrm{~cm} /$ hour & Critical \\
\hline 7. & pH $\left(\mathrm{H}_{2} \mathrm{O}\right) 1: 2,5$ & $<4.5 ;>8.5$ & 6.6 & not Critical \\
\hline 8. & $\begin{array}{l}\text { Electrical } \\
\text { Conductivity }\end{array}$ & $4.0 \mathrm{mS} / \mathrm{cm}$ & $0.228 \mathrm{mS} / \mathrm{cm}$ & not Critical \\
\hline 9. & redox & $<200 \mathrm{mV}$ & $64.1 \mathrm{mV}$ & Critical \\
\hline 10. & number of Microbes & $<10^{2} \mathrm{cfu} / \mathrm{g}$ soil & $\begin{array}{l}\text { Bacteria }>300 \mathrm{X} 10^{9} \\
\text { Mushrooms 3 X } 10^{9}\end{array}$ & not Critical \\
\hline
\end{tabular}

Note: Exceeding $=$ Critical

No $=$ Not Critical

Moor inBhinorvillage, Paiton subdistrict indicatedcritical land with constraints on the parameters of water discharge and redox degrees. The degree of water discharge is $0.20 \mathrm{~cm} /$ 
hour passing critical limit and indicated that there is problem on the rate of water entering the ground, as a result, nutrients are swept away by the water following the flow of the surface that carry fertilizer in it. Waterlogged or flooded land tends to experience flooding due to slowflow ofwater into the ground. The redox is lowthat soil is frequently poisoned byFe and Mn that affect plant growth.

The solution for this problem is to reduce intensive tillage with minimum processing and making drainage channels. To improve the soil, organic fertilizer from cow manure can be usedto create nutrients and ongoing harvest. The use of organic pesticides is more advisable to increase soil porosity.

\subsubsection{Jabung Village (Rice Irrigation)}

Table 5. Results of Analysis and Interpretation of JabungSisirVillage Land Damage (SI), Paiton Sub district,Probolinggo.

\begin{tabular}{|c|c|c|c|c|}
\hline No. & Parameter & $\begin{array}{l}\text { Critical threshold } \\
\text { (PP150 / 2000) }\end{array}$ & $\begin{array}{l}\text { Observations } \\
\text { Analysis }\end{array}$ & $\begin{array}{l}\text { Exceeded } \\
\text { Not }\end{array}$ \\
\hline 1. & Solumn thickness & $<20 \mathrm{~cm}$ & $>90 \mathrm{~cm}$ & not Critical \\
\hline 2. & Surface rocks & $40 \%$ & $<5 \%$ & not Critical \\
\hline 3. & fraction composition & \begin{tabular}{|l|}
$<18 \%$ colloidal \\
$80 \% \quad$ sand \\
kuarsitik
\end{tabular} & $4.46 \%$ & not Critical \\
\hline 4. & weight content & $1.4 \mathrm{~g} / \mathrm{cm}^{3}$ & $1.38 \mathrm{~g} / \mathrm{cm}^{3}$ & not Critical \\
\hline 5. & porosity Total & $<30 \% ;>70 \%$ & $41.43 \%$ & not Critical \\
\hline 6. & $\begin{array}{l}\text { The degree of release } 0 \\
\text { water }\end{array}$ & $\begin{array}{l}\mathrm{f}<0.7 \mathrm{~cm} / \text { hour; } \\
8.0 \mathrm{~cm} / \text { hour }\end{array}$ & $0.04 \mathrm{~cm} /$ hour & Critical \\
\hline 7. & $\mathrm{pH}\left(\mathrm{H}_{2} \mathrm{O}\right) 1: 2,5$ & $<4.5 ;>8.5$ & 6.4 & not Critical \\
\hline 8. & Electrical Conductivity & $4.0 \mathrm{mS} / \mathrm{cm}$ & $0.154 \mathrm{mS} / \mathrm{cm}$ & not Critical \\
\hline 9. & redox & $<200 \mathrm{mV}$ & $48.9 \mathrm{mV}$ & Critical \\
\hline 10. & number of Microbes & $<10^{2} \mathrm{cfu} / \mathrm{g}$ soil & $\begin{array}{l}\text { Bacteria }>300 \times 10^{9} \\
\text { Fungi } 6 \times 10^{9}\end{array}$ & not Critical \\
\hline
\end{tabular}

Note: Exceeding = Critical

No $=$ Not Critical

Land inJabungSisir village, Paiton subdistrict indicated critical land with problem on degree of water discharge and redox. Based on the landcondition obtained by field research, the problems is identical to that ofBhinorvillage. The degree of water discharge is very low that a lot of water stagnate the surface of the land because of land compaction. The redox availability is low due to less supportive irrigationchannels, causing that plants cannot grow and develop well.

The solution to preserve the land is to create of irrigation channels and use organic fertilizers continuously in every tillage. Other land conservation efforts is also needs to be implemented to plant annual crops intercropped with seasonal crops and farmers should reduce the use of inorganic pesticides for land sustainability. 


\subsubsection{Alas Tengah}

Table 6. Results of Analysis and Interpretation of Land Damage in Alas Tengah Village, Paiton Sub district,Probolinggo

\begin{tabular}{|c|c|c|c|c|}
\hline No. & Parameter & $\begin{array}{l}\text { Critical threshold } \\
\text { (PP150 / 2000) }\end{array}$ & $\begin{array}{l}\text { Observations } \\
\text { Analysis }\end{array}$ & $\begin{array}{l}\text { Exceeded } \\
\text { Not }\end{array}$ \\
\hline 1. & Solumn thickness & $<20 \mathrm{~cm}$ & $>90 \mathrm{~cm}$ & not Critical \\
\hline 2. & Surface rocks & $40 \%$ & $<5 \%$ & not Critical \\
\hline 3. & fraction composition & $\begin{array}{|ll|}<18 \% \text { colloidal } \\
80 \% \quad \text { sand } \\
\text { kuarsitik }\end{array}$ & $12.07 \%$ & not Critical \\
\hline 4. & weight content & $1.4 \mathrm{~g} / \mathrm{cm}^{3}$ & $1.28 \mathrm{~g} / \mathrm{cm}^{3}$ & not Critical \\
\hline 5. & porosity Total & $<30 \% ;>70 \%$ & $44.36 \%$ & not Critical \\
\hline 6. & $\begin{array}{l}\text { The degree of release o } \\
\text { water }\end{array}$ & $\begin{array}{l}<0.7 \mathrm{~cm} / \text { hour; } \\
8.0 \mathrm{~cm} / \text { hour }\end{array}$ & $0.32 \mathrm{~cm} /$ hour & Critical \\
\hline 7. & $\mathrm{pH}\left(\mathrm{H}_{2} \mathrm{O}\right) 1: 2,5$ & $<4.5 ;>8.5$ & 6.9 & not Critical \\
\hline 8. & Electrical Conductivity & $4.0 \mathrm{mS} / \mathrm{cm}$ & $0.043 \mathrm{mS} / \mathrm{cm}$ & not Critical \\
\hline 9. & redox & $<200 \mathrm{mV}$ & $56.4 \mathrm{mV}$ & Critical \\
\hline 10. & number of Microbes & $<10^{2} \mathrm{cfu} / \mathrm{g}$ soil & \begin{tabular}{|l} 
Bacteria $>300 \times 10^{9}$ \\
Mushrooms 2 X $10^{9}$ \\
\end{tabular} & not Critical \\
\hline
\end{tabular}

Note: Exceeding $=$ Critical

No $=$ Not Critical

Soil in Alas Tengah Village, Paiton sub districtindicated problem on the degree of the water discharge and redox. The land problem in this area is similar to that of JabungSisisr village with the degree of water discharge is higher in the latter village yet with change in redox due to frequent cultivation that the land lost organic matter and the soil became more compact.

The existing problem can be addressed with irrigation channels and drainage, organic fertilizer with manure or harvest residue of hay or remnants of harvest along with minimal processingto improve redox. The use of organic pesticides is preferable because in addition to increase the number of bacteria and fungi also help the availability of organic matter in the soil.

\subsubsection{Kalijajar Wetan Village}

Table 7. Results of Analysis and Interpretation of Soil Damage in KalijajarWetan Village, PaitonSub district, Probolinggo.

\begin{tabular}{|l|l|l|l|l|}
\hline No. & Parameter & $\begin{array}{l}\text { Critical threshold } \\
(\mathrm{PP} 150 / 2000)\end{array}$ & $\begin{array}{l}\text { Observations } \\
\text { Analysis }\end{array}$ & $\begin{array}{l}\text { Exceeded } \\
\text { Not }\end{array}$ \\
\hline 1. & Solumn thickness & $<20 \mathrm{~cm}$ & $>90 \mathrm{~cm}$ & not Critical \\
\hline 2. & Surface rocks & $40 \%$ & $<3 \%$ & not Critical \\
\hline 3. & fraction composition & $\begin{array}{l}<18 \% \text { colloidal } \\
80 \% \quad \text { sand } \\
\text { kuarsitik }\end{array}$ & $5.66 \%$ & not Critical \\
\hline 4. & weight content & $1.4 \mathrm{~g} / \mathrm{cm}^{3}$ & $1.46 \mathrm{~g} / \mathrm{cm}^{3}$ & not Critical \\
\hline
\end{tabular}




\begin{tabular}{|l|l|l|l|l|}
\hline 5. & porosity Total & $<30 \% ;>70 \%$ & $33.22 \%$ & not Critical \\
\hline 6. & $\begin{array}{l}\text { The degree of release of } \\
\text { water }\end{array}$ & $\begin{array}{l}<0.7 \mathrm{~cm} / \text { hour; } \\
8.0 \mathrm{~cm} / \text { hour }\end{array}$ & $0.40 \mathrm{~cm} /$ hour & Critical \\
\hline 7. & $\mathrm{pH}\left(\mathrm{H}_{2} \mathrm{O}\right) 1: 2,5$ & $<4.5 ;>8.5$ & 6.2 & not Critical \\
\hline 8. & Electrical Conductivity & $4.0 \mathrm{mS} / \mathrm{cm}$ & $0.247 \mathrm{mS} / \mathrm{cm}$ & not Critical \\
\hline 9. & redox & $<200 \mathrm{mV}$ & $86.6 \mathrm{mV}$ & Critical \\
\hline 10. & number of Microbes & $<10^{2} \mathrm{cfu} / \mathrm{g}$ soil & $\begin{array}{l}\text { Bacteria }>300 \times 10^{9} \\
\text { Mushrooms } 11 \times 10^{9}\end{array}$ & not Critical \\
\hline
\end{tabular}

Note: Exceeding $=$ Critical

No $=$ Not Critical

The land in KalijajarWetan Village was in critical condition with problems in water discharge and redox degree, while there are vary alternative solutions available. The characteristic of land in KalijajarWetan village is also marked with problem of water movement patterns. The degree of water discharge was low that water movement is slow, this makes nutrients quickly be swept away by surface runoff so that plant roots grow poorly.Annual crop of this village grows better such as star fruitand mango tresswith improvements that need the participation of the whole community. The critical threshold for KalijajarWetan village area needs attentionto avoid critical threshold and reduction of physical and chemical properties of the soil.

The existing problem can be addressed by making irrigation and land management. This can be carried out by growing annual crop according to land suitability and reduce the degree of small water discharge with the use organic matter from cow dung and dry leaves.

\subsubsection{Plampang village ( Rice Irrigation)}

Table 8. Results of Analysis and Interpretation of PlampangVillage Land Damage (SI), PaitonSub district, Probolinggo.

\begin{tabular}{|c|c|c|c|c|c|}
\hline No. & Parameter & Parameter & \begin{tabular}{|l} 
Critical \\
threshold \\
(PP150 / 2000)
\end{tabular} & $\begin{array}{l}\text { Observations } \\
\text { Analysis }\end{array}$ & $\begin{array}{l}\text { Exceeded } \\
\text { Not }\end{array}$ \\
\hline 1. & Solumn thickness & Solum thickness & $<20 \mathrm{~cm}$ & $>90 \mathrm{~cm}$ & not Critical \\
\hline 2. & Surface rocks & Surface kebatuan & $40 \%$ & $<5 \%$ & not Critical \\
\hline 3. & $\begin{array}{l}\text { fraction } \\
\text { composition }\end{array}$ & $\begin{array}{l}\text { composition } \\
\text { fraction }\end{array}$ & \begin{tabular}{|lr}
$<18 \%$ & colloidal \\
$80 \%$ & sanc \\
kuarsitik &
\end{tabular} & $7,82 \%$ & not Critical \\
\hline 4. & weight content & weight content & $1.4 \mathrm{~g} / \mathrm{cm}^{3}$ & $1.39 \mathrm{~g} / \mathrm{cm}^{3}$ & not Critical \\
\hline 5. & porosity Total & porosity Total & <30\%;> 70\% & $38.32 \%$ & not Critical \\
\hline 6. & $\begin{array}{l}\text { The degree } \\
\text { release of water }\end{array}$ & $\begin{array}{l}\text { fhe degree } \\
\text { release of water }\end{array}$ & $\begin{array}{l}<0.7 \mathrm{~cm} / \text { hour; } \\
8.0 \mathrm{~cm} / \text { hour }\end{array}$ & $3.50 \mathrm{~cm} /$ hour & not Critical \\
\hline 7. & $\mathrm{pH}\left(\mathrm{H}_{2} \mathrm{O}\right) 1: 2,5$ & $\mathrm{pH}\left(\mathrm{H}_{2} \mathrm{O}\right) 1: 2,5$ & $\mid<4.5 ;>8.5$ & 6.5 & not Critical \\
\hline
\end{tabular}




\begin{tabular}{|c|c|c|c|c|c|}
\hline 8. & $\begin{array}{l}\text { Electrical } \\
\text { Conductivity }\end{array}$ & $\begin{array}{l}\text { Electrical } \\
\text { Conductivity }\end{array}$ & $4.0 \mathrm{mS} / \mathrm{cm}$ & $0.242 \mathrm{mS} / \mathrm{cm}$ & not Critical \\
\hline 9. & redox & redox & $<200 \mathrm{mV}$ & $58.7 \mathrm{mV}$ & Critical \\
\hline 10. & $\begin{array}{l}\text { number } \\
\text { Microbes }\end{array}$ & 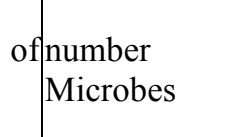 & of $<\begin{array}{lll}<10 & 2 & \\
\text { soil } & & \end{array}$ & $\left\{\begin{array}{l}\text { Bacteria } 43 \times 10 \\
7 \\
\text { mushrooms - }\end{array}\right.$ & Critical \\
\hline
\end{tabular}

Note: Exceeding = Critical

No $=$ Not Critical

Irrigation rice fieldindicated degraded land with problem initiated on redox and number of microbes. Water conductivity was low by $3.50 \mathrm{~cm} /$ hour or at critical limits indicated in nutrients lost to runoff andlow availability of organic material. The problems are indicated by firm ground structure and the soil is difficult to be destroyed due to bonding clay and sedimentary limestone.High rainfall and intensive land management makes upper soil layer lost. Land improvement by planting cover crop that soil is not easily lost and by giving crops remnants or organic fertilizer to improve soil organic matter content in the soil.

The number of redox was low by $58.7 \mathrm{mV}$ thatthe soil was dominated by Fe and $\mathrm{Mn}$ which can be poisonous and therefore contributes to a very few number of microbes. This makes bacteria cannot live optimally function as decomposers to provide availability of nutrientto plants and provide organic matter into the soil.Intensive cultivation of land cause land to loss its main nutrient of organic material.

The solution is to reduce intensive tillage or Minimum Tillage and planting cover crops. Plant intercropping of annual and seasonal crop can be also implemented that have benefits for maintaining water that it is not easily lost to prevent nutrient erosion on the surface layer of top soil. Soil maintenance can be also carried out according to the land conditions and post-harvest treatment with the returned harvested crops. The use of organic fertilizer from cow manure is also goodto maintain nutrient availability fromongoing harvest. The use of organic pesticides is recommended. Redox can be increasedwith seedbed that allows oxygen to enterthe soil, allowing oxidation process can run.

\section{Conclusion}

The following conclusion is drawn from the research:

1. Land that qualify as critical in accordance observations indicated low quality of land as a result of intensive land cultivation, low attention onpost-harvest handling regarding soil fertility level and continuousland use.

2. Villages in the Paitondistrictindicated problems that vary according to the condition of bulk density factor, the degree of water dischargeand influencing redox and microbes.

3. Establishing irrigationand drainage channels, Organic fertilizer usage by utilizing the manure from crop, crop rotation patterns and conservation of the land by planting vegetation and in accordance with the conditions are preferable to be carried out for each region.

4. Participation supportfrom the community for sustainable land.

\section{Reference}

1. BPS. Probolinggo (2014), the Central Statistics Agency Figures Probolinggo. Probolinggo, East Java. 
2. KLH. Repulic Indonesia. (2009), Preparation of Technical Guidelines Map Status Land Damage Biomass Production, Jakarta, 31Halaman.

3. K. Minister of Forestry, Nomor 20 / Kpts- Ii / (2001), About PU and Criteria and Standards of Forest and Land Rehabilitation, Jakarta.

4. P. Government Nomor 150 of the Year (2000), Land Degradation Control For Biomass Production, Jakarta.

5. PMLH. Nomor 07 Year (2006), Procedures Criteria, Damage Measurement of Soil Materials for Biomass Production, Jakarta.

6. Y.A. Butler, K. Wikantika, and F. Hadi, (2005), Spatial Analysis Critical Areas In North Bandung City Grass Using Open Source, Department of Geodesy, Faculty of Civil and Environmental Engineering, Institut Teknologi Bandung - ITB, Jl. Ganesha Nomor 10, Bandung, Indonesia.

7. KH. Tan (1991), Soil Chemistry Basics, UGM, Yogyakarta

8. WH. Utomo (1985), Soil Physics, Brawijaya University Press, Department of Soil Science, Faculty of Agriculture, University of Brawijaya, Poor.

9. Zhiddiq (2005), Mapping of Critical Areas Atlas, Your Community, Napier South Celebes Indonesia. 